\title{
Garlic extract improves budbreak of the 'Niagara Rosada' grapevines on sub-tropical regions
}

\author{
Extrato de alho melhora a superação da dormência de videiras 'Niagara Rosada' \\ em regiões subtropicais
}

\author{
Renato Vasconcelos Botelho ${ }^{\mathrm{I}}$ Erasmo José Paioli Pires ${ }^{\mathrm{II}}$ Mara Fernandes Moura \\ Maurilo Monteiro Terra' ${ }^{\text {II }}$ Marco Antonio Tecchio ${ }^{\text {II }}$
}

\begin{abstract}
In the regions with mild winters, usually the chilling requirements for bud dormancy release of grapevines are not fulfilled, and only the highly toxic products $\mathrm{CaCN}_{2}$ (calcium cyanamide) and $\mathrm{H}_{2} \mathrm{CN}_{2}$ (hydrogen cyanamide) are recommended in conventional viticulture for budbreak. The purpose of this study was to verify the effect of garlic extract on budbreak of 'Niagara Rosada' grapevines in two different vineyards. The highest dose of garlic extract $\left(70 \mathrm{~mL} \mathrm{~L}^{-1}\right)$ showed a great potential for budbreak in organic production, presenting similar effects of cyanamides in budbreak. This treatment improved the sprouting percentage, number of clusters, accelerated the beginning of sprouting and reduced the cycle between pruning and harvest.
\end{abstract}

Key words: agroecology, Vitis labrusca, sprouting, grapevine, endodormancy, Allium sativum.

\section{RESUMO}

Nas regiões com invernos amenos, normalmente as exigências de frio para a quebra de dormência de gemas de videiras não são atendidas, e apenas os produtos altamente tóxicos $\mathrm{CaCN}_{2}$ e $\mathrm{H}_{2} \mathrm{CN}_{2}$ são recomendados na viticultura convencional para quebra de dormência. A proposta deste estudo foi verificar o efeito do extrato de alho na quebra de dormencia de videiras 'Niagara Rosada', em dois diferentes vinhedos. A dose mais elevada de extrato de alho $\left(70 \mathrm{~mL} \mathrm{~L}^{-1}\right)$ demonstrou ter um grande potencial para a quebra de dormência na produção orgânica, apresentando efeitos similares aos das cianamidas, na quebra de dormência. Este tratamento aumentou a porcentagem de brotação e o número de cachos, antecipou o começo da brotação e reduziu o ciclo entre poda e colheita.

Palavras-chave: agroecologia, Vitis labrusca, brotação, endodormência, Alium sativum.

\section{INTRODUCTION}

The 'Niagara Rosada' grapevine (Vitis labrusca) is originated from a natural mutation of 'Niagara', an American grapevine introduced from Alabama (USA) that occurred in 1933, in São Paulo State, Brazil. This mutant grapevine supplanted the original 'Niagara' and is one of the most important table grape cultivar in Brazil (TECCHIO et al., 2009).

The grapevine, typical deciduous species of temperate climate, is broadly cultivated in tropical and subtropical areas, like the zones of São Paulo State, Southeastern region of Brazil. In such areas, the chilling requirement for budbreak are not fulfilled, leading to a late leafing, reduced and no regular sprouting and, consequently, decrease in yield, causing significant economic loses. Chilling exposing necessary for normal bud growth ranges between 50 and $400 \mathrm{~h}$ at temperatures of $7.0^{\circ} \mathrm{C}$, varying for each grapevine cultivar and 'Niagara Rosada' grapevines needs about $100 \mathrm{~h}$ (DOKOOZLIAN et al., 1998),

Previous literature indicates that the exposition of the buds to chilling inhibits the activity of the catalase, enzyme present in aerobics cells that decomposes the hydrogen peroxide $\left(\mathrm{H}_{2} \mathrm{O}_{2}\right)$ in molecular oxygen and $\mathrm{H}_{2} \mathrm{O}$ (NIR et al., 1986). Its physiologic function eliminates the excess of $\mathrm{H}_{2} \mathrm{O}_{2}$ produced during the cellular metabolism, avoiding its accumulation and consequent cellular damage. However, evidences have

'Departamento de Agronomia, Universidade Estadual do Centro-Oeste (Unicentro). Rua Simeão Varella de Sá, 03, 85040-080, Guarapuava, PR, Brasil. E-mail: rbotelho@unicentro.br. Autor para correspondência.

"Instituto Agronômico de Campinas (IAC). Campinas, SP, Brasil. 
shown that $\mathrm{H}_{2} \mathrm{O}_{2}$ acts as a chemical signal in response to biotic and abiotic stresses (BARTOSZ, 1997; FOYER et al., 1997).

After that, the plant leads to $\mathrm{H}_{2} \mathrm{O}_{2}$ deintoxication through a sequence of reactions connected to the pentose phosphate pathway, leading to an increase of reduced nucleotides $\mathrm{NAD}(\mathrm{P}) \mathrm{H}$, raising the metabolism and the induction of dormancy termination, bud burst and rapid growth (NIR et al., 1986). According to PINTO et al. (2007), these metabolic changes has as consequence the increase on the levels of AMP/ATP intracellular relation that induces proteinkinases SNF, that plays a role in the transduction signal system for endodormancy end of buds.

Nowadays, both calcium cyanamide $\left(\mathrm{CaCN}_{2}\right)$ and hydrogen cyanamide $\left(\mathrm{H}_{2} \mathrm{CN}_{2}\right)$ are recommended in Brazil for budbreak induction of grapevines, but $\mathrm{H}_{2} \mathrm{CN}_{2}$ is the mostly used in Brazil for all temperate zone fruits (HAWERROTH et al., 2010). For the Jundiaí region, in Brazil, $\mathrm{CaCN}_{2} 200 \mathrm{~g} \mathrm{~L}^{-1}$ or $\mathrm{H}_{2} \mathrm{CN}_{2} 25 \mathrm{~g} \mathrm{~L}^{-1}$ promoted budbreak of the grapevine 'Niagara Rosada' in $100 \%$ of the buds (PIRES et al., 1985).

In United States and in Italy the use of $\mathrm{H}_{2} \mathrm{CN}_{2}$ was estimated in 112,490 and $36,287 \mathrm{~kg}$, respectively, mainly in grapes. However, hydrogen cyanamide is highly toxic. The Environmental Protection Agency of the United States classifies this compound in the highest toxicity category (category I), and it has been under regulatory review by European Union authorities (SETTIMI et al., 2005). Accordingly to exposed, there is a necessity of new agents for dormancy break that are easily available, effective, low toxic and used in low concentrations.

Searching for new alternatives for budbreak, KUBOTA\& MIYAMUKI (1992) verified that garlic paste applied to cane cut surfaces of 'Muscat of Alexandria' grapevines, immediately after pruning, was more efficient than calcium cyanamide $\left(\mathrm{CaCN}_{2}\right)$, a substance typically used for vines in Japan. Satisfactory results were also obtained with $20 \%$ garlic oil in 'Pione' and 'Thompson Seedless' grapevines (KUBOTA et al., 2000). BOTELHO et al. (2007), observed $37 \%$ and $75 \%$ sprouted buds in cuttings of grapevines cv. Cabernet Sauvignon sprayed with garlic extract $3 \%$, submitted to 0 and 168 chilling hours $\left(=7,0^{\circ} \mathrm{C}\right)$, respectively, but this treatment were less effective than hydrogen cyanamide.

This study aimed to investigate the effect of the garlic extract, compared to the calcium cyanamide and hydrogen cyanamide on budbreak of 'Niagara Rosada’ grapevines.

\section{MATERIAL AND METHODS}

The experiment was carried out in two commercial 'Niagara Rosada' (Vitis labrusca) vineyards in São Paulo State, Southeastern region of Brazil: one located in Jundiaí, (23 $06^{\prime} \mathrm{S}$ and $46^{\circ} 55^{\prime} \mathrm{W}, 715 \mathrm{~m}$ a.s.1.); and another in Indaiatuba $\left(23^{\circ} 05^{\prime} \mathrm{S}\right.$ and $47^{\circ} 13^{\prime} \mathrm{W}$, and $630 \mathrm{~m}$ a.s.1.). The nine-year-old vines on the rootstock IAC-766 'Campinas' (106-8Mgt x Vitis caribaea) were spaced 2.0 by $1.0 \mathrm{~m}$ and trained to a unilateral cordon. The canes, six per cordon, were pruned to a single-bud spur in 26 July 2007, in Jundiai vineyard and; in 11 July 2007, in Indaiatuba.

The treatments were composed of the following commercial products: Bioalho ${ }^{\circledR}$ (garlic extract $700 \mathrm{~mL} \mathrm{~L}^{-1}$, Natural Rural Co.), Dormex ${ }^{\circledR}\left(\mathrm{H}_{2} \mathrm{CN}_{2} 490 \mathrm{~g} \mathrm{~L}^{-1}\right.$, Basf Co.) and Hiraguen- $\mathrm{S}^{\circledR}$ (Nonyl phenoxy poly (ethylene oxy) ethanol $200 \mathrm{~g} \mathrm{~L}^{-1}$, Hirarabrás Co.). Immediately after pruning, the following treatments were sprayed to 'drip point' at dormant bud stage using a hand driven sprayer: garlic extract (GE) at 0, 14, 28, 42, 56 e $70 \mathrm{~mL} \mathrm{~L}^{-1}$; calcium cyanamide $\left(\mathrm{CaCN}_{2}\right)$ at $200 \mathrm{~g} \mathrm{~L}^{-1}$ and hydrogen cyanamide $\left(\mathrm{H}_{2} \mathrm{CN}_{2}\right)$ at $25 \mathrm{~g} \mathrm{~L}^{-1}$. In all the solutions were added $20 \mathrm{~mL} \mathrm{~L}^{-1}$ of a no ionic adjuvant.

In each vineyard, the trial was laid out using a completely randomized design with eight treatments and six one-whole-plant replicates. Each vine plant was examined for the following variables: 1) sprouting time: number of days between pruning and begging of sprouting; 2) sprouting percentage: considered when no more evolution in bud sprouting was verified; 3) cycle length: number of days between pruning and harvest, 4) number of clusters per plant. Budbreak was regarded when a green tinge was seen beneath the bud scales; this evaluation was performed weekly. The harvest was carried out when the total soluble solids content of most grapes reached $15^{\circ}$ Brix.

All data were analyzed statistically using the ANOVA in the SANEST statistical package (ZONTA \& MACHADO, 1987). Meaningful comparisons were generated using Tukey's test $(5 \%$ level) and regression analysis.

\section{RESULT AND DISCUSSION}

In both vineyards, the time for sprouting beginning after pruning was linearly reduced in function of garlic extract doses, anticipating 30 days in Indaiatuba and 6 days in Jundiaí for the highest dose (70 $\mathrm{mL} \mathrm{L}^{-1}$ ) (Figures $1 \mathrm{~A}$ and $\left.1 \mathrm{~B}\right)$. The conventional treatments with $\mathrm{CaCN}_{2}$ and $\mathrm{H}_{2} \mathrm{CN}_{2}$ were the most effectives for accelerate bud sprouting, but they did not differ of the GE at 56 and $70 \mathrm{~mL} \mathrm{~L}^{-1}$ in Indaiatuba 


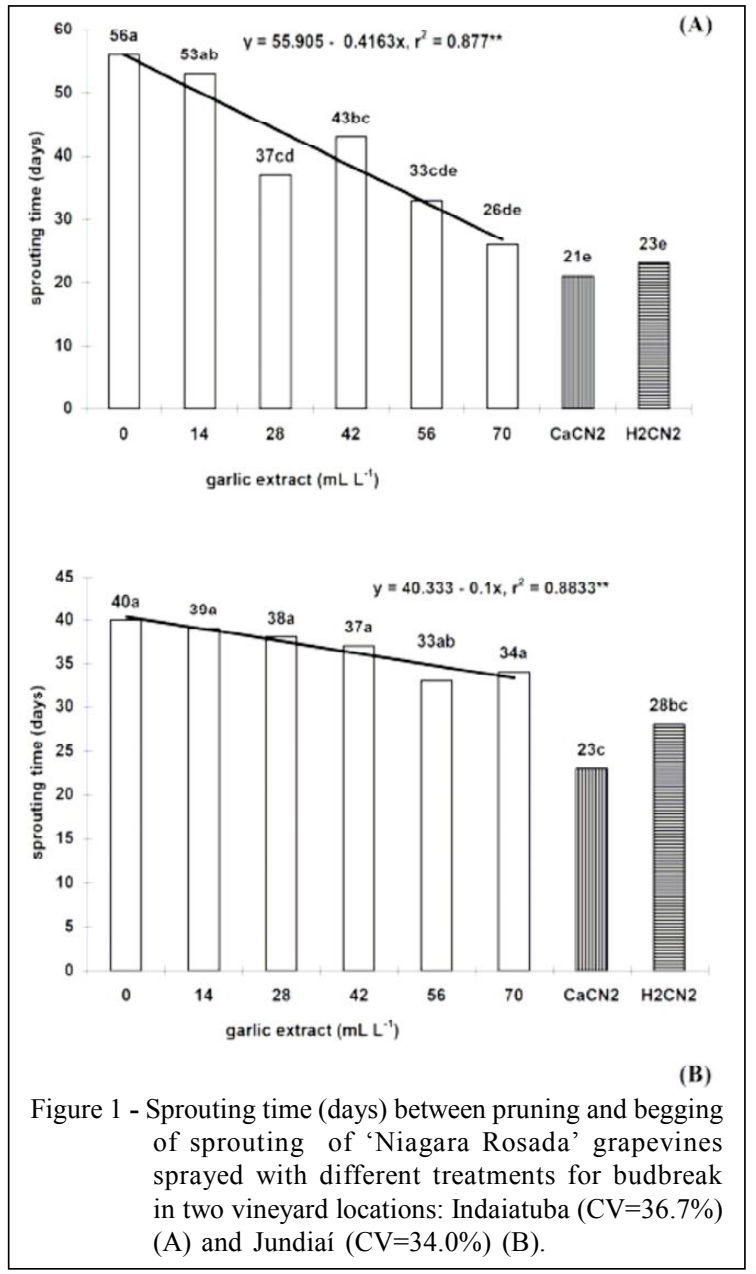

vineyard (Figure 1A) and, GE at $56 \mathrm{~mL} \mathrm{~L}^{-1}$ did not differ from $\mathrm{H}_{2} \mathrm{CN}_{2}$, in Jundiaí vineyard (Figure 1B) .

The sprouting percentage was linearly increased with garlic extract doses, in Indaiatuba and Jundiaí vineyards (Figure 2A and 2B). The highest values for bud sprouting was verified for the treatments with $\mathrm{CaCN}_{2}$ and $\mathrm{H}_{2} \mathrm{CN}_{2}$, reaching $100 \%$, although they were similar to the garlic extract $70 \mathrm{~mL} \mathrm{~L}^{-1}$, that attained 89 and $94 \%$ of sprouted buds compared to only 56 and $75 \%$ in control plants, in Indaiatuba and Jundiaí, respectively.

The cycle between pruning and harvest was linearly decreased in both vineyards in relation to garlic extract doses, but the shortest cycles were observed for the conventional treatments with $\mathrm{CaCN}_{2}$ and $\mathrm{H}_{2} \mathrm{CN}_{2}$, completing 124 and 130 days for both treatments, in Indaiatuba and Jundiaí, respectively. In control plants the cycle was 185 days in Indaiatuba and 150 days in Jundiaí (Figures $3 \mathrm{~A}$ and 3B, respectively).

The number of clusters per plant was improved with increasing doses of garlic extract
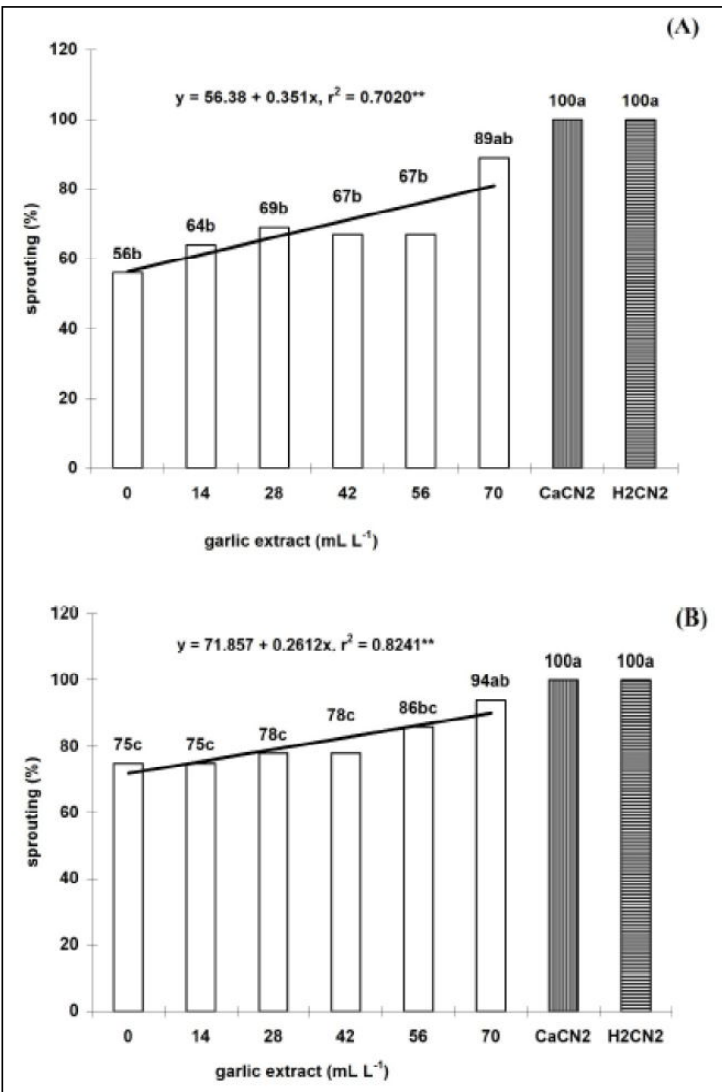

Figure 2 - Percentage of sprouting of 'Niagara Rosada' grapevines sprayed with different treatments for budbreak in two vineyard locations: Indaiatuba $(\mathrm{CV}=26.3 \%)(\mathrm{A})$ and Jundiaí (CV=9.7\%) (B).

showing a quadratic effect in both vineyards locations (Figures 4A and 4B). The conventional treatments for budbreak with $\mathrm{CaCN}_{2}$ and $\mathrm{H}_{2} \mathrm{CN}_{2}$ showed the highest values for number of clusters, but they did not differ from the treatment with GE at $70 \mathrm{~mL} \mathrm{~L}^{-1}$, in Indaiatuba and Jundiaí.

In this experiment, the best results for budbreak were verified for $\mathrm{CaCN}_{2}$ and $\mathrm{H}_{2} \mathrm{CN}_{2}$ treatments. Similarly, BOTELHO et al. (2002) verified that applications of $3.0 \% \mathrm{H}_{2} \mathrm{CN}_{2}$ to nonchilled Centennial Seedless grapevines induced about $70 \%$ budbreak after two weeks from treatment date, while buds on control vines attained only $30 \%$. In Cabernet Sauvignon grapevines, MIELE (1991) observed maximum percentage of bud burst with concentrations between $1.8 \%$ and $1.9 \%$ hydrogen cyanamide in Rio Grande do Sul State, Brazil. PÉREZ \& LIRA (2005) demonstrated that $\mathrm{H}_{2} \mathrm{CN}_{2}$ inhibited competitively the activity of catalase. In this case, a shortening in bud endodormancy could be related to catalase inhibition through $\mathrm{H}_{2} \mathrm{O}_{2}$ accumulations in bud tissues. An excess of $\mathrm{H}_{2} \mathrm{O}_{2}$ could 


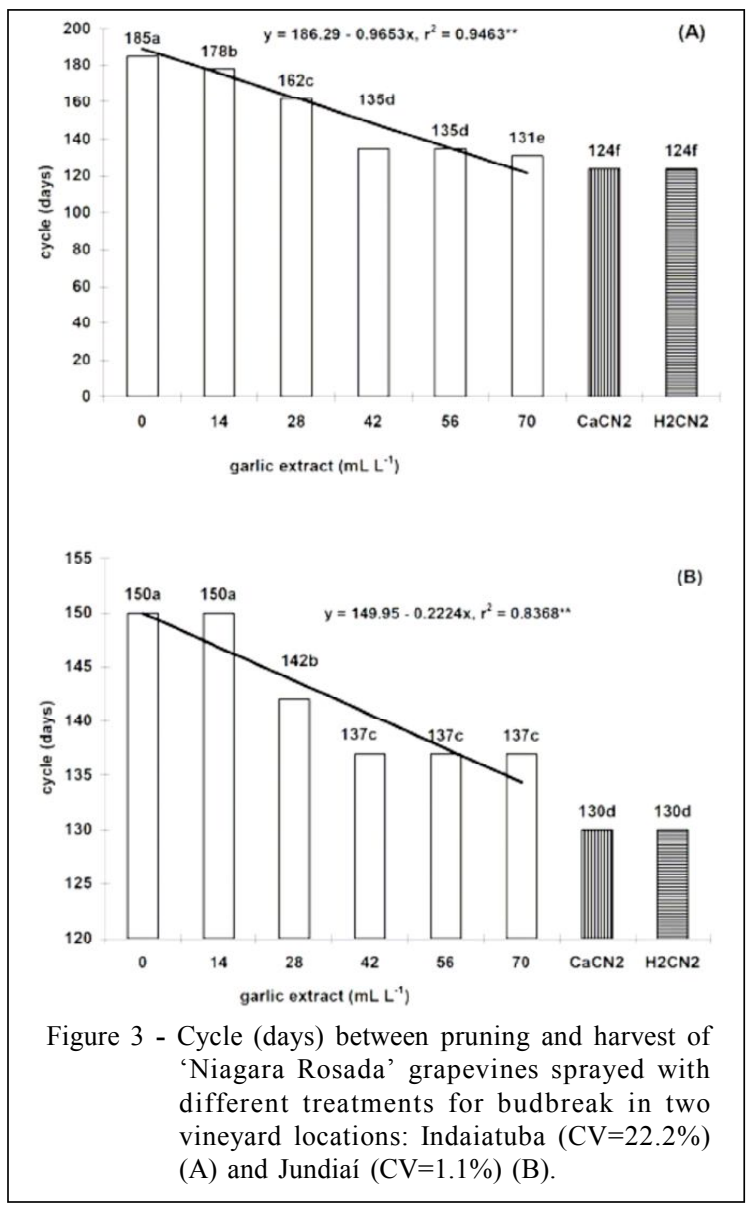

generate an oxidative stress or act as chemical signal that triggers the expression of genes related to endodormancy release.

Garlic extract treatments also promoted bud sprouting, similar then the standard treatments with cyanamides. Similar results were verified with the use of garlic-based compounds in grapevines, but using much more concentrated solutions (from 20 to $100 \%$ ) (KUBOTA \& MIYAMUKI, 1992; KUBOTA et al., 1999a,b, 2000). According to KUBOTA et al. (2002) the active substances in garlic responsible for breaking bud dormancy are volatile compounds containing sulfur and an allyl group $\left(\mathrm{CH}_{2} \mathrm{CHCH}_{2}\right)$, specially the diallyl dissulfide, which is the most abundant sulfide in garlic. Exposure of grapevine cuttings to volatiles from grated garlic and commercial garlic oil promoted budbreak (KUBOTA et al., 1999a) and exposures to volatiles of diallyl di- and tri-sulfides were also effective (KUBOTA et al., 1999b).

However, the physiological role of these compounds on the breaking bud dormancy in no chilled grapevines was not established (KUBOTA et al., 2000).

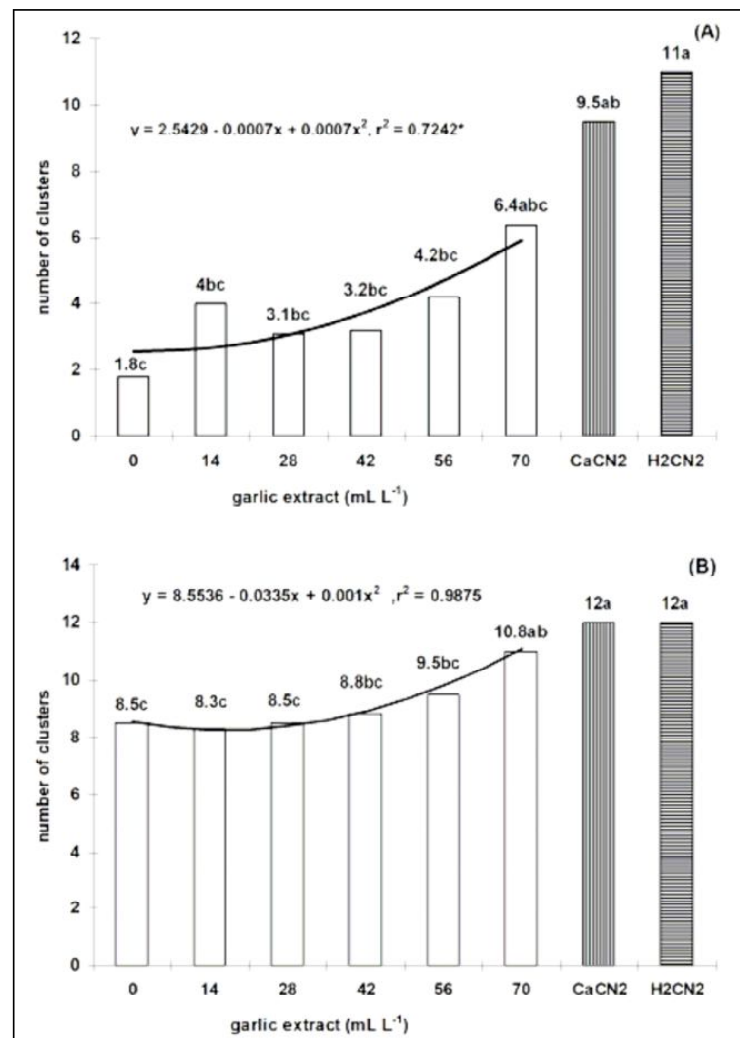

Figure 4 - Number of clusters per plant of 'Niagara Rosada' grapevines sprayed with different treatments for budbreak in two vineyard locations: Indaiatuba $(\mathrm{CV}=66.6 \%)(\mathrm{A})$ and Jundiaí $(\mathrm{CV}=11.8 \%)(\mathrm{B})$.

Probably, these substances would actuate by the same mechanism proposed by PINTO et al. (2007) as a result of oxidative stress through accumulation of $\mathrm{H}_{2} \mathrm{O}_{2}$. LEMAR et al. (2005) observed that the application of garlic extract caused an oxidative stress in cells of Candida albicans, but in this case this would lead to the inhibition of the growth of this fungus colonies and the destruction of its cellular components.

Bioalho ${ }^{\circledR}$ (garlic extract) is a natural product recommended as insect repellent for organic production systems, according to current Brazilian legislation. It is obtained from cold drawing out of garlic extract by press and this formulation is totally soluble in water. The GE at $70 \mathrm{~mL} \mathrm{~L}^{-1}$ promoted 'Niagara Rosada' grapevines budbreak and could be recommended for agroecologic viticulture. Although, cyanamide treatments were more effective; these products show high toxicity and is not allowed for organic fruit production.

In spite of the promising results showed by the treatment with GE in field conditions, the results are still preliminary, needing new researches, mainly 
aiming the increase of economical viability and the reduction of doses, for example with the use of different adjuvants. According to DOKOOZLIAN et al. (1998), the scales of the buds vines, that protect them against dry up and extreme climatic conditions, are a barrier for products used for the dormancy break. In this case, the adjuvants could increase the penetration of the products in the bud, increasing its efficiency.

\section{CONCLUSION}

The effect of the treatment with garlic extract $70 \mathrm{~mL} \mathrm{~L}^{-1}$ on budbreak of the 'Niagara Rosada' grapevines was similar to the conventional treatments with $\mathrm{CaCN}_{2} 200 \mathrm{~g} \mathrm{~L}^{-1}$ or $\mathrm{H}_{2} \mathrm{CN}_{2} 25 \mathrm{~g} \mathrm{~L}^{-1}$ in both vineyard locations. These treatments also reduced the time for beginning of sprouting and the cycle from pruning to harvest and increased the number of cluster per plant. Garlic extract could be used in substitution of $\mathrm{CaCN}_{2}$ or $\mathrm{H}_{2} \mathrm{CN}_{2}$ in agroecologic vineyard.

\section{REFERENCES}

BARTOSZ, G. Oxidative stress in plants. Acta Physiologiae Plantarum, Heidelberg, v.19, p.47-64, 1997. Available from: $<$ http://www.springerlink.com/content/m2j84138t548/ ? $\mathrm{p}=\mathrm{b} 48 \mathrm{f} 5216 \mathrm{ba} 1 \mathrm{~d} 4 \mathrm{edabeb} 2 \mathrm{bb} 3 \mathrm{c} 1 \mathrm{f} 61185 \mathrm{~d} \& \mathrm{pi}=64>$. Accessed: Jan 07, 2009. doi: 10.1007/s11738-997-0022-9.

BOTELHO, R.V. et al. Brotação e produtividade de videiras da cultivar Centennial Seedless (Vitis vinifera L.) tratadas com cianamida hidrogenada na região noroeste do estado de São Paulo. Revista Brasileira de Fruticultura, Jaboticabal, v.24, n.3, p.611-614, 2002. Available from: $<$ http://www.scielo.br/ scielo.php? script=sci_arttext \& pid = S $0100-$ 29452002000300007\&lng=en\&nrm=iso $>$. Accessed: Sep 1, 2010. doi: $10.1590 / \mathrm{S} 0100-29452002000300007$.

BOTELHO, R.V. et al. Effects of chilling and garlic extract on bud dormancy release in Cabernet Sauvignon grapevine cuttings. American Journal of Enology and Viticulture, Davis, v.58, p.402-404, 2007. Available from: $<\mathrm{http}: / /$ www.ajevonline.org/ content/vol58/issue3/index.dtl>. Accessed: Dec 20, 2007.

DOKOOZLIAN, N.K. et al. Surfactants improve the response of grapevines to hydrogen cyanamide. HortScience, Alexandria, v.33, n.5, p.857-859, 1998. Available from: <http:/ /hortsci.ashspublications.org/content/vol33/issue5/index.dtl $>$. Accessed: Dec 20, 2008.

FOYER, C.H. et al. Hydrogen peroxide and glutathione associated mechanisms of acclamatory stress tolerance and signaling. Physiologia Plantarum, Hoboken v.100, n.2, 241-254, 1997. Available from: <http://www3.interscience.wiley.com/journal/ 119168585/issue>. Accessed: May 13, 2009. doi: 10.1111/ j.1399-3054.1997.tb04780.x.

HAWERROTH, F. J. et al. Brotação de gemas em macieiras 'Imperial Gala' e 'Fuji Suprema' pelo uso de Erger® e nitrato de cálcio. Revista Brasileira de Fruticultura, Jaboticabal, v.32, n.2, p.343-350, 2010. Available from: $<$ http://www.scielo.br/ s c i e lo.ph p s c ri pt=s ci art text \& pid=S $0100-$ 29452010000200002\&lng $=$ en $\& \bar{n} r m=i s o>$. Accessed: Sep 01, 2010. doi: 10.1590/S0100-29452010005000074.

KUBOTA, N.; MIYAMUKI, M. Breaking bud dormancy in grapevines with garlic paste. Journal of the American Society for Horticultural Science, Alexandria, v.117, n.6, p.898-901, 1992. Available from: http://journal.ashspublications.org/cgi/ reprint/117/6/898?>. Accessed: Jan 15, 2009.

KUBOTA, N. et al. Breaking bud dormancy in grapevine cuttings with garlic volatiles. Journal of the Japanese Society for Horticultural Science, Kioto, v.68, n.5, p.927-931, 1999a. Available from: $<$ http://www.journalarchive.jst.go.jp/english/ jnlabstract_en.php?cdjournal $=$ jjshs $1925 \& \mathrm{cdvol}=68 \&$ noissue $=5 \&$ sta rtpage $=92>$. Accessed: Jul 18, 2009. doi:10.2503/jjshs.68.927

KUBOTA, N. et al. Identification of active substances in garlic responsible for breaking bud dormancy in grapevines. Journal of the Japanese Society for Horticultural Science, Kioto, v.68, n.6, p.1111-1117, 1999b. Available from: <http://www.journalarchive.jst.go.jp/ jnlpdf.php?cdjournal $=$ jjshs $1925 \& \mathrm{cdvol}=68 \&$ noissue $=6 \&$ startpage $=11$ 11\&lang=en\&from=jnltoc $>$. Accessed: Sep 20, 2009. doi:10.2503/ jjshs.68.1111.

KUBOTA, N. et al. Effects of garlic preparations and calcium and hydrogen cyanamides on budbreak of grapevines grown in greenhouses. American Journal of Enology and Viticulture, Davis, v.5, n.4, p.409-414, 2000. Available from: <http:// www.ajevonline.org/cgi/reprint/51/4/409>. Accessed: Nov 15, 2008 .

KUBOTA, N. et al. Breaking bud dormancy in grape cuttings with nonvolatile and volatile compounds of several Allium species. Journal of the Japanese Society for Horticultural Science, v.71, n.4, p.467472, 2002. Available from: <http://www.journalarchive.jst.go.jp/ jnlpdf.php? cdjournal=jjshs $1925 \& \mathrm{cdvol}=71 \&$ no issue $=4 \&$ startpage $=467 \&$ lang $=$ en $\&$ from $=$ jnltoc $>$. Accessed: Nov 17, 2009. doi:10.2503/jjshs.71.467.

LEMAR, K.M. et al. Allyl alcohol and garlic (Allium sativum) extract produces oxidative in Candida albicans. Microbiology, Reading, n.10, v.151, p.3257-3265, 2005. Available from: <http://mic.sgmjournals.org/cgi/reprint/151/10/ 3257>. Accessed: Dec 20, 2009. doi: 10.1099/mic.0.28095-0.

MIELE, A. Efeito da cianamida hidrogenada na quebra de dormência das gemas, produtividade do vinhedo e composição química do mosto da uva Cabernet Sauvignon. Pesquisa Agropecuária Brasileira, Brasília, v.26, n.3, p.315-324, 1991.

NIR, G. Changes in the activity of catalase in relation to the dormancy of grapevine (Vitis vinifera L) buds. Plant Physiology, Waterbury, v.81, n.4, p.1140-1142, 1986. Available from: <http://www.plantphysiol.org/cgi/reprint/81/4/ 1140>. Accessed: Nov 13, 2009. doi:10.1104/pp.81.4.1140.

PÉREZ, F.J.; LIRA, W. Possible role of catalase in post-dormancy bud break in grapevines. Journal of Plant Physiology, Waterbury, v.162, n.3, p.301-308, 2005. Available from: <http:/ /www.sciencedirect.com/science/journal/01761617> Accessed: Dec 12, 2009. doi:10.1016/j.jplph.2004.07.011. 
PINTO, M. Fisiologia de la latencia de las yemas de vid: hipótesis actuales. Santiago: Universidad de Chile, 2007. 16p. Available from: <http://agronomia.uchile.cl/extension/ serviciosyproductos/gie/publicaciones>. Accessed: Dec 24, 2007.

PIRES, E.J.P. et al. Ação de calciocianamida e alzodef na época de brotação e produtividade da videira 'Niagara Rosada'. Anais da Escola Superior de Agricultura "Luiz de Queiroz", v.42, n.2, p.469-479, 1985

SETTIMI, L. et al. Update: hydrogen cyanamide-related illnesses. Morbidity and Mortality Weekly Report, v.54, n.16, p.405-408, 2005. Available from: <http://www.cdc.gov/ mmwr/preview/mmwrhtml/mm5416a3.htm>. Accessed: Apr 13,2010 .

TECCHIO, M.A. et al. Efeito do ácido naftalenoacético e do cloreto de cálcio na redução das perdas pós-colheita em uva 'Niagara Rosada'. Revista Brasileira de Fruticultura, Jaboticabal, v.31, n.1, p.53-61, 2009. Available from: <http://www.scielo.br/ scielo.php?script $=$ sci_arttext\&pid $=$ S010029452009000100009\& lng-pt\&nrm=iso $>$. Accessed: Sep 01, 2010. doi: 10.1590/S010029452009000100009.

ZONTA, E.P.; MACHADO, A.A. SANEST - Sistema de análise estatística para microcomputadores. Pelotas: DMEC/IFM/UFPel, 1987. 138p. 